\title{
Effect of Nymphaea meal incorporated diets on growth, feed efficiency and body composition in fingerlings of Cyprinus carpio $\mathrm{L}$.
}

\section{G. Sivani, D.C. Reddy and M . Bhaskar*}

Division of Animal Biotechnology, Department of Zoology, Sri Venkateswara University, Tirupati - 517 502. (A.P), INDIA

*Corresponding author. E-mail: matchabhaskar@yahoo.com

Received: D ecember 27, 2012; Revi sed received: J anuary 5, 2013; Accepted: J anuary 10, 2013

Abstract: The effect of varying levels of Nymphaea leaf meal on the growth and survival of common carp, Cyprinus carpio was investigated. In a feeding trail of 45 days, three experimental diets containing nymphaea leaf meal at 300,400 and $500 \mathrm{~g} \mathrm{~kg}^{-1}$ level of incorporation were fed to triplicate groups of 10 fish each. The conventional feed used in India, consisting of a mixture of groundnut oil cake and rice bran in 1:1 ratio served as the control. Best growth in terms of weight gain $(35.2 \mathrm{~g})$, specific growth rate (4.67), protein efficiency ratio (PER) (2.7), feed conversion ratio (FCR) (2.5) was obtained for the test diet with $400 \mathrm{~g} \mathrm{~kg}^{-1}$ nymphaea meal inclusion level. However no statistical difference was observed between the three experimental diets. Digestive enzyme activity and digestibility studies also indicated the same pattern. Thus the results of the present study indicate that a diet of $300 \mathrm{~g} \mathrm{~kg}^{-1}$ overall protein with nymphaea meal included at $400 \mathrm{~g} \mathrm{~kg}^{-1}$ can elicit good growth response and survival in common carp.

Keywords: Cyprinus carpio, Digestibility, Enzyme activity, Growth, Nymphaea meal

\section{INTRODUCTION}

In fish farming, nutrition is critical because feed represents $60 \%-71 \%$ of the production costs (De Silva, 1985), thus fish nutrition investigations are mainly directed towards reducing feed cost by manipulating the feed formulation. In contrast to quality commercial prawn feeds that are readily available in India, there is a acute paucity of nutritionally sound, cost-effective feeds for finfish in general, and for, in particular. The traditional feed mixture employed in the culture of Indian Major Carp (IMC) is unbalanced. There is, therefore, an urgent need to develop low-cost, nutritionally balanced IMC diets that can support increased production levels. The reduced availability as well as the escalating cost of fish meal has necessitated the need to identify suitable costeffective alternatives to fish meal.

Consequently, identification and evaluation of alternative protein sources to fish meal is a top research priority in fish nutrition. Considerable attention has been devoted to the evaluation of plant protein such as soy bean meal, solvent extracted cotton seed meal, lupin meals, various legumes (cow pea, green mung bean, rice bran), leaf meals, and papaya or Canote leaf meal (Ramachandran and Ray, 2007, Latif et al., 2008, Lim and Lee, 2008, Tahir et al., 2008, Dadgar et al., 2009, Gut et al., 2010, Pavan Kumar et al., 2011) as ingredients in feeds of aquatic animals. The present study evaluates the possibility of utilizing Nymphaea leaf meal in diets for the common carp Cyprinus carpio by assessment of its growth response to varying levels of $\mathrm{N}$ ymphaea leaf meal in the diet.

\section{MATERIALS AND METHODS}

Fingerlings of $C$. carpio obtained from the Carp Seed Production Center, Kalyani Dam, Tirupati were used for the study. The weight of the individuals ranged from 1.50 to $1.55 \mathrm{~g}$. The fish were acclimated to experimental conditions for a fortnight prior to the start of the trail. Fish were fed with conventional feed during acclimatization and feeding was suspended two days before the commencement of the experiment.

Four test diets designated as P30, P40, P50 and Control Diet (CD) were used. The three test diets had Nymphaea leaf powder incorporation at levels 300,400 and 500g per $\mathrm{kg}$ respectively. The last diet which severed as the control was typical of the traditional diets used in India and contained groundnut oil cake and rice bran in a 1:1 ratio for $30 \mathrm{~min}$. The crude protein levels of the four diets were 27.00 (CD), 28.01 (P30), 29.32 (P40) and 31.94 (P50) respectively. The percentage composition of the feed ingredients of the various test diets is presented in Table 1.

All the feed ingredients were dried and powdered. Ingredients were mixed with sufficient quantity of water to get the required soft consistency and hand kneaded. It was then cooked in a pressure cooker for $30 \mathrm{~min}$. The cooked feed was cooled by spreading under the fan, vitamin mineral premix was added and mixed uniformly. The feed was sun dried and analyzed for proximate composition and stored in plastic containers.

Moisture content (Boyd, 1979), crude protein and crude fat (by using Tecator Kjeltec and Soxhlet apparatus respectively, AOAC, 1975): Crude fibre (Pearson, 1976) 
and carbohydrate (Nitrogen Free Extract - NFE) (Hastings, 1976) were analyzed. Total ash was determined by burning the sample for $6 \mathrm{hrs}$ in Muffle furnace.

Trails were conducted for a period of 45 days in 80 lit cylindrical fiber glass tanks filled with filtered fresh water. Each treatment had three replications as per a completely randomized design. 10 carp fingerling were randomly distributed in each tank after recording the individual wet weight $(\mathrm{g})$. The feed was given ad libitum once daily and the leftover feed was collected every day and weighted. Ten percent of the water was exchanged daily and aeration was provided. Growth was assessed by sampling fortnightly, wherein total weight of the sampled fish was recorded. At the end of the experiment, total weight and the number of surviving fish in each experimental unit were noted. Water quality parameters, viz. temperature, $\mathrm{pH}$ and dissolved oxygen (Classical Winkler method) were monitored fortnightly.

The evaluation criteria were percentage weight gain, specific growth rate (SGR), feed conversion ratio (FCR), protein efficiency ratio (PER) and percentage survival.

Weight gain $=$ average final weight - average initial weight.

$\%$ weight gain $=\frac{\text { Average final weight }- \text { average initial weight }}{\text { Average initial weight }} \times 100$

$\mathrm{FCR}=$ feed intake $(\mathrm{g}) /$ live weight gain $(\mathrm{g})$.

PER = live weight gain $(\mathrm{g}) /$ Protein intake $(\mathrm{g})$

SGR $\%=\frac{\log _{\mathrm{e}} \mathrm{W}_{\mathrm{t}}-\log _{\mathrm{e}} \mathrm{W}_{0}}{\mathrm{~T}} \times 100$

Where, $\mathrm{W}_{\mathrm{t}}$ is the weight $(\mathrm{g})$ attained after specific period of time ' $\mathrm{t}$ ' of experiment, $\mathrm{W}_{0}$ the weight $(\mathrm{g})$ at ' 0 ' day of experiment and' $t$ ' the days of experiment.

$\%$ survival $=($ initial number stocked - number of dead $) X$ $100 /$ initial number stocked.

At the end of the experiment, fish from each experiment unit were killed. The fish muscle devoid of bones was dried and analyzed for proximate composition. Digestive enzymes like amylase, protease and lipase were determined from different treatment groups at the termination of the experiment. Intestinal tract was isolated from the freshly killed fish and immediately transferred to chilled watch glass containing $0.65 \%$ cold saline. Intestinal segments were slit open longitudinally and thoroughly washed with cold saline to remove the debris. All the tissue segments were blotted dry, weighed, homogenized and centrifuged at 10,000 rpm for $10 \mathrm{~min}$ and the supernatant was used for the enzyme study. Enzyme concentrations were expressed as $\mu$ moles of product liberated $\mathrm{mg}^{-1}$ protein $\mathrm{min}^{-1}$. Protein in the crude enzyme extract was measured by Lowry et al. (1951) using Bovine serum albumin as the standard. Total protease activity was measured by casein digestion method (Kunitz, 1947), Amylase activity ( $\alpha$-amylase was measured by the method of Bernfeld (1955) while Bier's titrimetric (Bier, 1962) was used for the estimation of lipase activity with minor modifications. Apparent nutrient digestibility was estimated by the method of Furukawa and Tsukuhara (1957).

Analysis of variance (ANOVA) was performed and transformation was obtained on percentage values before subjecting them to analysis (Snedecor and Cochran, 1968).

\section{RESULTS}

The proximate composition of the test diets $\mathrm{P} 30, \mathrm{P} 40, \mathrm{P} 50$ and CD in the study is presented in Table 2 . The crude protein level varied from 27.00 to 31.94 . The mean value of percentage weight gain, SGR, FCR, PER and survival rate are presented in Table 3 . The maximum weight gain $(35.2 \mathrm{~g})$ was observed in the P40 treatment group and lowest $(21.7 \mathrm{~g})$ was recorded in the control treatment group that has a significantly lowest percentage weight gain than all the test diets. The SGR revealed the same pattern, where in the values were minimum (3.17) in control treatment group and maximum (4.67) in P40 diet group. The FCR in the control group significantly differed from all other test diets with the poorest conversion (3.1) being in the control and best (2.5) in the P40 treatment group. The PER was significantly different between each of the diets. The survival rate of $\mathrm{P} 40$ groups was not significantly different from that of the other groups.

The carcass composition of the fish fed with different test diets is presented in Table 4. The results revealed that the moisture content in the control diet group did not differ from other groups feed with the test diets, while the protein and the lipid contents differed significantly among the fish fed the test diets.

Intestinal protease and lipase activities were found to be directly related to the levels of dietary protein and lipids.

Table 1. Composition of feed ingredients in different feeds (in $\mathrm{g}$ per $\mathrm{kg}$ feed).

\begin{tabular}{lcccc}
\hline Ingredient & Contr ol diet (CD) & \multicolumn{2}{c}{ Experimental diets } \\
\cline { 3 - 5 } & & P 30 & P 40 \\
\hline Rice bran & 39 & 24 & 19 & 14 \\
Ground nut oil cake & 39 & 24 & 19 & 14 \\
Soybean meal & 20 & 20 & 20 & 20 \\
Nymphaea leaf meal & - & 30 & 40 & 2 \\
Vitamin - mineral premix & 2 & 2 & 2 \\
\hline
\end{tabular}


Table 2. Proximate composition of test diets $\left(\mathrm{g} \mathrm{kg}^{-1}\right)$.

\begin{tabular}{lcccc}
\hline Parameter & CD & \multicolumn{3}{c}{ Experimental diets } \\
\cline { 2 - 5 } & & P 30 & P 40 & P 50 \\
\hline Moisture & $9.02 \pm 0.12$ & $8.97 \pm 0.33$ & $8.93 \pm 0.41$ & $8.89 \pm 0.86$ \\
Crude protein & $27.00 \pm 0.21$ & $28.01 \pm 0.54$ & $29.32 \pm 0.43$ & $31.94 \pm 0.78$ \\
Lipid & $4.69 \pm 0.43$ & $4.67 \pm 0.21$ & $4.60 \pm 0.86$ & $4.56 \pm 0.42$ \\
Crude fibre & $11.08 \pm 0.33$ & $11.78 \pm 0.69$ & $11.95 \pm 0.58$ & $11.81 \pm 0.92$ \\
Ash & $9.04 \pm 0.76$ & $8.59 \pm 0.91$ & $8.13 \pm 0.16$ & $7.64 \pm 0.37$ \\
\hline
\end{tabular}

Gut amylase activity increased with increase in dietary protein level. Higher digestibilities of protein and fat were found with the three experimental diets than the control diet, indicating the ability of common carp to digest Nymphaea leaf protein. Protein digestibility was found to increase with increase in dietary protein levels in the test diets. Reverse trend however was observed in lipid digestibility.

\section{DISCUSSION}

Results of the present study demonstrated that water quality parameters were within the optimal range of fish production on par with the study of Banarjee (1967) and indicated water quality did not produce any stress on fish during experiment. The results indicated the positive influence of the test diets in the fingerlings of common carp. Daily consumption was variable but the mean consumption did not differ significantly among the plant substituted diets. Growth was observed to increase with increase in Nymphaea leaf meal only up to the level of $40 \%$ inclusion (P30, P40) and the growth performance and feed utilization efficiency decreased thereafter with increase in Nymphaea leaf meal incorporation. This could be attributed to the reduced digestibility at higher percentage Nymphaea leaf meal incorporation due to higher carbohydrate content. It has been reported that reduced digestibility with increased carbohydrate content is related to actual reduction in gland stimulation, and enzyme reduction (Falge et al., 1978). The PER, FCR and SGR observed in the present study are on par with the observations made by Ramachandran and Ray (2007), Tahir et al. (2008) and Pavankumar et al. (2011). Carcass composition (Table 4) also indicated that protein deposition was higher with lower incorporation level.
Similar observations were made by Patra et al. (2000) in C irrhinus mrigala with Nymphoides leaf meal where $30 \%$ incorporation was found to give better growth rate than $60 \%$ incorporation. Feed utilization in 45 day reared fingerlings was significantly higher in test diet fed groups compared to control fed groups. The poor FCRs recorded in all treatments except for $\mathrm{P} 30$ diet. This could be related to high fibre content of Nymphaea leaf meal which might have played an important role in feed conversion efficiency that varied at different time intervals. Fischer (1972) reported that large grass pellets containing fairly large amounts of crude fibre affected digestibility and food conversion. Not only high fibre content but also high ash content (12\%) of Nymphaea leaf powder in the test diets might have contributed to a better conversion. This observation derives support from the studies of Tan (1970) who fed several types of vegetation to grass carp (Ctenopharyndon idella) in pond and found $\mathrm{H}$ ydrilla to be an excellent food because of the soft nature of the plant (low fibre) and high mineral content.

Carcass quality is a matter of great importance from the perspective of consumer acceptance. Increase in muscle protein and lipid content of fish fed on test diets could be ascribed to the efficiency of common carp to digest plant ingredients as an energy supplement for growth.

Table 5 shows the gut enzyme activity of common carp. Intestinal protease activity increased with an increase in the Nymphaea meal inclusion up to $40 \%$ inclusion level, after that the protease activity decreased. A reduction in the activity of lipase was observed at higher levels of Nymphaea meal inclusion, while the amylase activity increased with increase in Nymphaea meal incorporation. The protein digestibility data support the growth trend (Table 5). While the protein digestibility of three test

Table 3. Growth parameters and survival of Cyprinus carpio fed different diets.

\begin{tabular}{lcccc}
\hline Parameter & CD & \multicolumn{3}{c}{ Experimental diets } \\
\cline { 2 - 5 } & & P 30 & P 40 & P 50 \\
\hline Initial weight $(\mathrm{g})$ & $1.50 \pm 0.2$ & $1.51 \pm 0.1$ & $1.50 \pm 0.1$ & $1.50 \pm 0.1$ \\
Final weight $(\mathrm{g})$ & $23.2 \pm 0.1$ & $31.01 \pm 0.1$ & $36.7 \pm 0.2$ & $35.1 \pm 0.2$ \\
Weight gain $(\mathrm{g})$ & $21.7 \pm 0.3$ & $29.5 \pm 0.2$ & $35.2 \pm 0.2$ & $33.6 \pm 0.3$ \\
SGR & $3.17 \pm 0.5$ & $4.12 \pm 0.8$ & $4.67 \pm 0.3$ & $4.31 \pm 0.9$ \\
FCR & $3.1 \pm 0.1$ & $2.9 \pm 0.03$ & $2.5 \pm 0.01$ & $2.7 \pm 0.1$ \\
PER & $1.9 \pm 0.001$ & $2.1 \pm 0.001$ & $2.7 \pm 0.01$ & $2.4 \pm 0.04$ \\
\hline
\end{tabular}


Table 4. Proximate composition of fish muscle of common carp fed different diets (percentage).

\begin{tabular}{lcccc}
\hline Parameters (\%) & CD & \multicolumn{3}{c}{ Experimental diets } \\
\cline { 2 - 5 } & & $61.7 \pm 1.4$ & $61.7 \pm 1.1$ & $61.6 \pm 1.8$ \\
Moisture & $61.8 \pm 1.8$ & $20.4 \pm 1.7$ & $21.5 \pm 1.3$ & $20.9 \pm 1.9$ \\
Crude protein & $19.0 \pm 1.4$ & $3.67 \pm 0.4$ & $3.59 \pm 0.4$ & $3.58 \pm 0.1$ \\
Crude lipid & $3.74 \pm 0.1$ & $2.22 \pm 0.2$ & $2.54 \pm 0.7$ & $2.35 \pm 0.5$ \\
Ash & $2.08 \pm 0.3$ & $12.01 \pm 0.3$ & $10.67 \pm 0.1$ & $11.57 \pm 0.4$ \\
NFE & $13.38 \pm 0.7$ & & & P 30 \\
\hline
\end{tabular}

Table 5. Gut enzyme activity ( $\mu$ mol product liberated $\min ^{-1} \mathrm{mg}$ protein ${ }^{-1}$ at $37^{\circ} \mathrm{C}$ ) and apparent digestibility $(\%)$ of the test diets.

\begin{tabular}{|c|c|c|c|c|c|}
\hline \multirow[t]{2}{*}{ Diets } & \multirow[t]{2}{*}{ Protease } & \multirow[t]{2}{*}{ Lipase } & \multirow[t]{2}{*}{ Amylase } & \multicolumn{2}{|c|}{ A pparent digestibility } \\
\hline & & & & Protein & Lipio \\
\hline $\mathrm{CD}$ & 0.162 & 0.010 & 0.995 & 81.73 & 80.50 \\
\hline P30 & 0.187 & 0.015 & 1.082 & 87.93 & 84.31 \\
\hline P40 & 0.215 & 0.013 & 1.192 & 89.23 & 83.15 \\
\hline P50 & 0.199 & 0.011 & 1.212 & 88.45 & 81.67 \\
\hline
\end{tabular}

diets did not differ significantly between the treatments. It was significantly better than the control diet. Digestibility evaluation studies with common carp showed that the maximum protein digestibility can be obtained at an incorporation level of $40 \%$ in a 30\% protein diet. There is a great reduction in the fat digestibility at higher Nymphaea meal incorporation levels. The better digestibility of protein must be a result of better absorption since the protease activity showed the same pattern. Hepher (1988) reported rich intestinal bacterial also take part in other nutritional functions such as nonprotein nitrogen utilization and synthesis of Vitamin $B_{12}$ and Nicotinic acid (Teshima and Kashiwada, 1967; 1969). The higher growth rate of fish with the test diets could thus be attributed to protein sparing by carbohydrates. The present study clearly indicated that feeding fish with high levels of Nymphaea leaf meal (P 50 diet) has not yielded positive results. Only optimum levels of incorporation $40 \%$ yielded better results in terms of growth. Similar observations were made by Fynn-Aikins et al. (1992). It was further observed that better growth and production with Nymphaea leaf meal may be partly due to its fibre content, as the optimum level of crude fibre is beneficial in improving the utilization of certain nutrients (Steffens, 1981) and partly due to better utilization of the Nymphaea based diet.

Thus the present study suggests that Nymphaea leaf meal could be used as a source of dietary protein for common carp. This study also revealed that the fingerling of common carp grow well on the diets of $28 \%$ and $32 \%$ protein under laboratory probably as a consequence of optimum percentage of protein and also probably due to efficient utilization of diets.

\section{REFERENCES}

AOAC (1975). Official methods of analysis. Association of
Analytical Chemists. Washington. DC

Banarjee, S.M. (1967). Water quality and soil conditions of fish ponds in some states of India in relation to fish production. Indian J. Fish., 14, 115-125.

Bernfeld, P. (1955). Amylase $\alpha$ and $\beta$, In: Methods in Enzymology, Vol. I (ed. By S.P. Colowick \& N.O. Kaplan). P149. Academic press, New York.

Bier, M. (1962). Lipases. In: Methods in Enzymology, Vol. I (Ed. By S.P. Colowick \& N.O. Kaplan). Academic press, New York. pp. 627-642.

Boyd, D.C. (1979). Water quality, In: Warm water fish ponds, Auburn University, Agricultural experimental station. Alabama. pp.359.

Dadgar, S., Saad,C.R., Kamarudin, M.S., Alimon, A.R., Harmin, S., Satar, M.K.A., Arshad, A and Nafisi, M. (2009). Partial or total replacement of soybean meal with Iranian cottonseed meal in diets for rainbow trout ( 0 ncorhynkus mykiss). Res. J. of Fish and Hydrobiologia., 4 (1):22-28.

De Silva, S.S. (1985) Performance of Oreochromis niloticus(L) fry maintained on mixed feeding schedules of different protein content. Aquaculture and $\mathrm{F}$ isheries Management, $16,331-340$.

Falge, R., Schpanof, L. and Jurss, K. (1978) Amylase, esterase and protease activity in the intestine content of rainbow trout salmo gairdneri ricch after feeding with feed containing different amounts of starch and protein. J. Ichthyol., 48, 283-287.

Fischer, Z. (1972). The elements of energy balance in grass carp (Ctenopharyngodon idella) part III. Assimibility of proteins, carbohydrates and lipids by fishseed with plant and animal food. Pols. Arch. Hydrobiologia, 19, 83-95.

Furukawa, A and Tsukuhara, H. (1957). On the acid digestion method for the determination of chromic oxide as an index substance in the study of digestibility of fish feed. Bull. J ap. Soc. Sci. Fish. 32: 502-506.

Fynn-Aikins,K., Silas, S.O., Hung,S.S.O. and Huges, S.G. (1992) Effects of feeding a fish $h$ igh level D-glucose on liver function in juvenile white sturgeon (Acipenser transmontanus). Fish. Phy. \& Bioch.,12, 317-325.

Gut, D., Liu, W., Shao, X. and Xu, W. (2010). Effects of different 
dietary levels of cotton seed meal protein hydrolysate on growth, digestibility, body composition and serum biochemical indices in crucian carp (Carassius auratus gibelio). Anim. Feed Sci. and Technol., 156: 112-120.

Hastings, W.H. (1976). Fish nutrition and fish feed manufacture. FAO Technical Conf. on Aquaculture, Kyoto, Japan, FIR: AQ/conf/76/R. 23:13.

Hepher, B. (1988). Nutrition of pond fishes. Cambridge University press, Cambridge.

Kunitz, M. (1947). Crystalline trypsin inhibitor II. General properties. J ournal of $\mathrm{G}$ eneral Physiology, 30: 297-310.

Latif, K.A., Alam, M.T., Sayeed, M.A., Hussain, M.A., Sultana, S. and Hossain, M.A. (2008). Comparative study on the effects of low cost oil seed cakes and fish meal as dietary protein sources for Labeo rohita (Hamilton) fingerlings. U niv. J . Zool. Rajashahi. U niv., 27, 25-30.

Lim, S.J. and Lee, K.J.,(2008). Supplemental iron and phosphorus increase dietary inclusion of cotton seed and soybean meal in olive flounder (Paralichthys olivaceus), Aquaculture. N utr., 14. 423-430.

Lowry, C.H., Rosebrough, N.J., Farr, A.L. and Randall, R.J. (1951). Protein measurement with the Folin-Phenol reagent. I. Biol. Chem., 193: 265-275

Patra, S.S., Mukhopadhya, A.K. and Saha, C. (2000). Effect of Nymphoides leaf meal incorporated diets on growth and body composition in Cirrhinus mrigala . In: The fifth Indian fisheries forum (pp 77-79), India, Asian Fisheries Society, Indian branch, Mangalore.

Pavan Kumar, B., Chamundeswari Devi, B., Ravindrakumar Reddy, D. and Balasubramanian, A. (2011). Effect of cottonseed meal inclusion in diets of Catla catla (Hamilton, 1822). Continental J . Fisheries and Aquatic Sciences 5 (3): 14-18.

Pearson, D. (1976). The chemical analysis of Food. Churchill, London.

Ramachandran, S. and Ray, A.K. (2007). Nutritional evaluation of fermented black gram (Phase olus mango) seed meal in compound diets for rohu Labeo rohita (Hamilton) fingerlings. J . Appl. Ichthyol., 23., 74-7.

Snedecor, G.W and Cochran, W.G. (1968). Statistical methods. Oxford and IBH publishing Co., Calcutta, 593.

Steffens, W. (1981) Protein utilization of rainbow trout (Salmo gairdneri) and carp (Cyprinus carpio) : A brief review, Aquaculture, 23, 337-345.

Tahir, M.Z.A., ahmed, I., Mateen, A., Ashraf, M., Naqvi, Z.H. and Ali, H. (2008). Studies on partial replacement of fish meal with oil seeds meal in the diet of major carps. Int. J. Agr. Biol., 10 (4): 455-458.

Tan, Y.T., (1970). Composition and nutritive value of some grasses, plants, and aquatic weeds tested as diets, J. Fish.Biol., 2,253-257.

Teshima, S. and Kashiwada, K. (1967). Studies on the production of B vitamins by intestinal bacteria of fish. III. Isolation of vitamin B12 synthesizing bacteria and their bacteriological properties. Bull. J ap. Soc. Sci. Fish., 33, 97983.

Teshima, S. and Kashiwada, K. (1969). Studies on the production of B vitamins by intestinal bacteria of fish. IV Production of nicotinic acid by intestinal bacteria of carp. Mem. Fac. Fish, Kagoshima Univ., 18, 87 - 91. 